\title{
The therapeutic use of isometamidium chloride against Cryptobia salmositica in rainbow trout Oncorhynchus mykiss
}

\author{
B. F. Ardelli, P. T. K. Woo* \\ Department of Zoology, College of Biological Science, University of Guelph, Guelph, Ontario N1G 2W1, Canada
}

\begin{abstract}
Rainbow trout Oncorhynchus mykiss injected intramuscularly with isometamidium chloride $\left(0.01\right.$ or $\left.0.1 \mathrm{mg} \mathrm{kg}^{-1}\right)$ at 3 wk post-infection and given a booster 2 wk later had significantly lower parasitaemias than infected controls. Packed cell volume increased after treatment and remained higher than in infected controls. The concentration of isometamidium in plasma was highest at $2 \mathrm{wk}$ after injection and then declined. An intramuscular dose of $1.0 \mathrm{mg} \mathrm{kg}^{-1}$ of isometamidium chloride at 1 , 2 and $3 \mathrm{wk}$ postinfection (preclinical) significantly reduced the parasitaemia in rainbow trout 2 wk after treatment. A booster at $9 \mathrm{wk}$ postinfection (chronic disease phase) reduced the parasitaemia further in all fish. The packed cell volume in these fish was higher than in infected controls. Treatment at 5,6 , and 7 wk postinfection (acute disease) had no effects and parasitaemias in treated fish were higher than in infected controls; also, anti-Cryptobia salmositica antibodies and titres of complement-fixing antibody were higher in these than in infected controls. Incubation of immune plasma or complement with isometamidium for $3 \mathrm{~h}$ did not affect the lytic titres of complement-fixing antibodies nor rainbow trout complement.
\end{abstract}

KEY WORDS: Cryptobia salmositica Isometamidium chloride · Oncorhynchus mykiss

\section{INTRODUCTION}

Cryptobia salmositica is a pathogen of Oncorhynchus spp. on the West coast of North America (Bower \& Margolis 1984) and causes significant mortalities in post-spawning rainbow trout $O$. mykiss and prespawning chinook salmon $O$. tshawytscha (Woo \& Poynton 1995). The clinical signs of disease in experimentally infected rainbow trout include exophthalmia, a microcytic and hypochromic anaemia, splenomegaly, general oedema, abdominal distention with ascites and anorexia (Woo 1979, Li \& Woo 1991). The immune system of infected $O$. mykiss is depressed (Jones et al. 1986) and the haemolytic activity of complement is lower (Thomas \& Woo 1989). There are 3 distinct disease phases in rainbow trout infected with $C$. salmositica. During the preclinical phase the parasitaemia is low and the fish is not anaemic. In the acute phase the number of parasites is high and it fluctuates, and the

\footnotetext{
•Addressee for correspondence. E-mail: pwoo@uoguelph.ca
}

anaemia is severe (Woo 1979) with extensive necrosis in the liver and kidney and depletion of haemopoetic tissues (Bahmanrokh \& Woo 1994). At recovery phase there is regeneration and replacement of necrotic tissues and this is associated with reduced parasitaemia in the blood.

Wild stocks of rainbow trout Oncorhynchus mykiss sometimes die from cryptobiosis and significant mortality is associated with post-spawning trout (Wales \& Wolf 1955). Isometamidium chloride is used routinely to treat mammalian trypanosomiasis (Kinabo et al. 1989) and one of its actions is to cause the decantention of DNA in the kinetoplast-mitochondrion complex of the parasite. Since Cryptobia salmositica has a mitochondrial structure (Paterson \& Woo 1983) similar to the mammalian trypansomes, we decided isometamidium would be a good candidate drug against the parasite. The objectives of the present study were to investigate the effects of isometamidium chloride on $C$. salmositica at preclinical, acute and chronic phases of disease in rainbow trout. 


\section{MATERIALS AND METHODS}

In vitro culture of Cryptobia salmositica. A cloned strain of C. salmositica was used to infect rainbow trout held at $10^{\circ} \mathrm{C}$. The strain was initially isolated from Piscicola salmositica and details of the cloning of the parasite and fish maintenance have been described earlier (Woo 1979). The pathogenicity and infectivity of $C$. salmositica is maintained by serial passage in rainbow trout. For in vitro studies, blood from an infected trout was withdrawn and inoculated aseptically into sterile flasks containing Minimum Essential Medium (MEM) supplemented with Hank's salts, L-glutamine, $25 \mathrm{mM}$ Hepes buffer, and $25 \%$ heat-inactivated fetal bovine serum (FBS), and cultured (Woo \& Li 1990). The parasite was maintained in MEM for no longer than $8 \mathrm{wk}$ as the pathogen retained its pathogenicity to trout on short-term culture (Woo \& Thomas 1991).

Maintenance of fish. All rainbow trout used in the present study were obtained from Silvercreek Aquaculture Inc. (PO Box 399, Erin, Ontario NOB 1T0, Canada). Fish were maintained in $125 \mathrm{l}$ tanks with equatorial photoperiod in aerated ( $1 / 4$ cubic $\mathrm{ft} \mathrm{min}^{-1}$ ) recirculating well water $\left(10^{\circ} \mathrm{C}\right)$. Fish were fed a $52 \%$ protein diet (Martin Feed Mills, Elmira, Ontario N3B 3A2, Canada) daily and food was provided ad libitum (Ardelli \& Woo 1998).

Enzyme-linked immunosorbent assay to detect Cryptobia salmositica antibodies in plasma of fish (Sitja-Bobadilla \& Woo 1994). C. salmositica from culture were washed 5 times by centrifugation in cold blooded vertebrate Ringer's solution (CBVR). The pellet obtained was resuspended in CBVR and frozen at $-20^{\circ} \mathrm{C}$. The antigen (whole cell lysate) was prepared by freeze-thawing 5 times and by sonication. The protein concentration was estimated by the method of Bradford (1976) and diluted to a final concentration of $50 \mu \mathrm{g} \mathrm{ml}^{-1}$.

Briefly, the wells of a polystyrene microtitre plate were coated with $50 \mu \mathrm{l}$ of parasite antigen, incubated for $2 \mathrm{~h}$ at $37^{\circ} \mathrm{C}$ and washed 3 times with Tris-buffered saline (TBS, $\mathrm{pH}$ 7.5) and 3 times with Tween-tris buffered saline (TTBS). All subsequent washings were performed in this manner. Vacant sites were blocked with $200 \mu \mathrm{l}$ of $5 \%$ skim milk powder in TBS at $37^{\circ} \mathrm{C}$ for $1 \mathrm{~h}$, washed, and $50 \mu \mathrm{l}$ of test sample added. After incubation at $37^{\circ} \mathrm{C}$ for $2 \mathrm{~h}$, plates were washed and $50 \mu \mathrm{l}$ of a 1:1000 dilution of (in 3\% skim milk in TTBS) affinity purified peroxidase labelled goat anti-rainbow trout antibody (Kirkegaard and Perry, Mississauga, Ontario) was added. Plates were incubated $\left(1 \mathrm{~h}\right.$ at $\left.37^{\circ} \mathrm{C}\right)$, washed and $50 \mu$ l of 2,2 -azino-di-[3-ethyl-benzthiazoline sulfonate (6)] was added. Plates were shaken for $1 \mathrm{~min}$ and absorbence read at $405 \mathrm{~nm}$ using a MolecuIar Devices Vmax kinetic microplate reader. Controls consisted of no first antibody (test sample), no second antibody (goat anti-trout antibody), no antigen and enzyme substrate only.

In vitro immune lysis to detect complement fixing antibody against the parasite (Ardelli et al. 1994). Plasma was heat-inactivated for $30 \mathrm{~min}$ at $40^{\circ} \mathrm{C}$ (Sakai 1981). Heat-inactivated plasma was $(25 \mu \mathrm{l})$ dispensed into a well in a microtitre plate which was kept on ice. Plasma was then serially diluted (2-fold dilutions) in $25 \mu \mathrm{l}$ of cold CBVR, and incubated with $25 \mu \mathrm{l}$ of fresh rainbow trout complement and $25 \mu$ of CBVR containing 500 living washed Cryptobia salmositica from a parasite culture. The mixture was incubated at $11^{\circ} \mathrm{C}$ for $3 \mathrm{~h}$ and the microtitre plate was examined under a microscope (ocular $10 \times$, objective $10 \times$ ) for living parasites. The end point was the dilution at which all parasites were lysed.

In a similar experiment immune plasma was obtained from 8 trout that had been infected with Cryptobia salmositica, heat inactivated and divided into 2 groups. One group was incubated $\left(11^{\circ} \mathrm{C}\right.$ for $\left.3 \mathrm{~h}\right)$ with $0.02 \mathrm{mg} \mathrm{m}^{-1}$ of isometamidium (the concentration in fish blood determined using an ELISA) and the other without. Immune plasma was serially diluted and incubated with complement $(25 \mu \mathrm{l})$ and $25 \mu \mathrm{l}$ of CBVR containing 500 living parasites. The lytic titres were determined.

In another experiment fresh rainbow trout complement was obtained and divided into 2 aliquots; one was incubated with $0.02 \mathrm{mg} \mathrm{ml}^{-1}$ of isometamidium chloride $\left(11^{\circ} \mathrm{C}\right.$ for $\left.3 \mathrm{~h}\right)$ and the other without the drug. In vitro immune lysis was performed using the 2 aliquots of complement and the same immune plasma (without drug) as the previous experiment. Controls were wells containing Cryptobia salmositica in CBVR or MEM and wells containing parasites in immune plasma without the addition of complement. The lytic titres were determined as described earlier.

Antigen-capture enzyme-linked immunosorbent assay to detect isometamidium in fish plasma (Ardelli \& Woo 1999). The wells of a 96 -well polystyrene microtitre plate were coated with $50 \mu$ l of a 1:1000 dilution of anti-isometamidium antibodies in carbonate-bicarbonate coating buffer, $\mathrm{pH}$ 7.3. Plates were placed at $37^{\circ} \mathrm{C}$ for $2 \mathrm{~h}$ and washed twice in TBS and twice in TTBS. Vacant sites in the wells were blocked with $200 \mu$ of $5 \%$ skim milk in TBS for 1 h at $37^{\circ} \mathrm{C}$ and then washed. $50 \mu \mathrm{l}$ of test sample was added to each well, incubated for $2 \mathrm{~h}$ at $37^{\circ} \mathrm{C}$, washed and $50 \mu \mathrm{l}$ of a $1: 1000$ dilution of anti-isometamidium antibodies (in $3 \% \mathrm{skim}$ in TTBS) was added. After $2 \mathrm{~h}$ at $37^{\circ} \mathrm{C}$ the plates were washed and a 1:1000 dilution (in 3\% skim milk) of affinity purified peroxidase labelled goat anti-trout antibodies was added. After $1 \mathrm{~h}$ at $37^{\circ} \mathrm{C}$ plates were washed and $50 \mu \mathrm{l}$ of 2,2'-azino-di-[3-ethyl-benzthiazoline sulfonate (6)] was added. Plates were shaken for 1 min and 
absorbence read at $405 \mathrm{~nm}$ using a Molecular Devices Vmax kinetic microplate reader. Controls consisted of wells containing no antigen, or no first antibody, or no second antibody or enzyme substrate only.

In vivo effects of isometamidium chloride on Cryptobia salmositica in Oncorhynchus mykiss. Drug treatment at pre-acute infection: Thirty juvenile disease-free rainbow trout were randomly divided into 3 groups (Group A: $122.42 \pm 19.51 \mathrm{~g}$ laverage \pm standard deviation]; Group B: $140.33 \pm 27.31$ g; Group C: 130.93 $\left.\pm 31.15 \mathrm{~g}_{i} \mathrm{n}=10 \mathrm{group}^{-1}\right)$. Blood samples $\left(0.1 \mathrm{ml} \mathrm{fish}^{-1}\right)$ were obtained from the caudal vein prior to infection and packed cell volumes (PCV) were determined using the haematocrit centrifuge technique (Woo \& Wehnert 1983). Each group was inoculated intraperitoneally (i.p.) with $0.3 \mathrm{ml} \mathrm{CBVR} \mathrm{fish}{ }^{-1}$ containing $100000 \mathrm{C}$. salmositica from a fish. At 3 wk postinfection, Group A (infected controls) was inoculated intramuscularly (i.m.) with $0.2 \mathrm{ml}$ of CBVR, Group B was inoculated i.m. with $0.2 \mathrm{ml}$ of isometamidium chloride $(0.01 \mathrm{mg}$ $\mathrm{kg}^{-1}$ fish), and Group C was inoculated i.m. with $0.2 \mathrm{ml}$ of isometamidium chloride $\left(0.1 \mathrm{mg} \mathrm{kg}^{-1}\right.$ fish). Each group was given a second dose of the same treatment at $5 \mathrm{wk}$ postinfection. The 2 doses $(0.2 \mathrm{ml}$ of 0.1 or $0.01 \mathrm{mg} \mathrm{kg}^{-1}$ ) were injected i.m. at 2 different sites $\left(0.1 \mathrm{ml} \mathrm{site^{-1 }}\right)$, on the dorsal surface adjacent to the dorsal fin. Blood samples $\left(0.1 \mathrm{ml} \mathrm{fish}^{-1}\right)$ were obtained prior to infection and weekly for $7 \mathrm{wk}$ postinfection. Parasitaemias were determined for each group using a haemocytometer (Archer 1965) and PCV according to Woo \& Wehnert (1983). Isometamidium concentrations in plasma were also determined (see above).

Drug treatment at preclinical and at chronic cryptobiosis: Sixty juvenile disease free rainbow trout were divided into 5 groups (Group D: $196.99 \pm 39.79 \mathrm{~g}, \mathrm{n}=$ 10; Group E: $199.71 \pm 37.38 \mathrm{~g}, \mathrm{n}=10$; Group F: 182.28 $\pm 37.71 \mathrm{~g}, \mathrm{n}=20$; Group G: $182.10 \pm 26.16 \mathrm{~g}, \mathrm{n}=10$; Group H: $195.34 \pm 59.22 \mathrm{~g}, \mathrm{n}=10$ group $^{-1}$ ). Groups D, $\mathrm{F}, \mathrm{G}$, and $\mathrm{H}$ were inoculated i.p. with $0.3 \mathrm{ml}$ CBVR fish $^{-1}$ containing 100000 pathogenic Cryptobia salmositica; Group E was inoculated i.m. with $1.0 \mathrm{mg} \mathrm{kg}^{-1}$ of isometamidium. At $1 \mathrm{wk}$ postinfection, 10 fish in Group F (sub-group F1) were inoculated i.m. with $1.0 \mathrm{mg} \mathrm{kg}^{-1}$ of isometamidium and 10 fish (sub-group F2) inoculated with $2.5 \mathrm{mg} \mathrm{kg}^{-1}$ of isometamidium. At $2 \mathrm{wk}$ postinfection Group $\mathrm{G}$ fish were treated with $1.0 \mathrm{mg} \mathrm{kg}^{-1}$ of isometamidium, and Group $\mathrm{H}$ fish were given the same dose at $3 \mathrm{wk}$ postinfection. At $9 \mathrm{wk}$ postinfection, Groups E, F, G, and $\mathrm{H}$ were inoculated intramuscularly with a further $1.0 \mathrm{mg} \mathrm{kg} \mathrm{kg}^{-1}$ of isometamidium. Blood samples were obtained prior to infection and weekly for 13 wk. Parasitaemias, PCV and isometamidium concentrations in plasma were determined each week.

Drug treatment at acute cryptobiosis: Expt 1: Forty disease-free rainbow trout were randomly divided into
4 groups (Group I: $256.42 \pm 61.05$ gi Group J: $245.15 \pm$ $41.41 \mathrm{~g}$; Group K: $251.34 \pm 71.23 \mathrm{~g}$; Group L: $269.65 \pm$ $63.02 \mathrm{~g}$ ). Each group ( $\mathrm{n}=10 \mathrm{group}^{-1}$ ) was inoculated i.p. with 100000 Cryptobia salmositica. Group J was treated i.m. with $1.0 \mathrm{mg} \mathrm{kg} \mathrm{g}^{-1}$ of isometamidium at $5 \mathrm{wk}$ postinfection, Group K at 6 wk postinfection, and Group L at 7 wk postinfection. Blood samples were obtained prior to infection and weekly between 4 and 9 wk after infection. Parasitaemias and PCV were determined as described.

Expt 2: Fifty disease-free rainbow trout (Group M: $637.2 \pm 197.86$ g; Group N: $653.73 \pm 167.87 \mathrm{~g}$; Group O: $638.61 \pm 298.18 \mathrm{~g}_{i}$ Group P: $613.30 \pm 185.76 \mathrm{~g}$; Group $\mathrm{Q}: 666.96 \pm 172.35 \mathrm{~g}, \mathrm{n}=10$ group $^{-1}$ ) were randomly divided into 5 groups. Each group except Group M (naive controls), was inoculated with 100000 Cryptobia salmositica and then treated at either 5 (Group O); or 6 (Group P) or 7 wk (Group Q) postinfection. Blood samples were obtained prior to infection and weekly for $9 \mathrm{wk}$ postinfection. Parasitaemias, PCV, anti-C. salmositica antibodies, complement fixing antibodies and concentrations of isometamidium in plasma were determined.

Statistical analysis. An analysis of variance (ANOVA) was used and statistical significance was evaluated at $p \geq 0.05$.

\section{RESULTS}

\section{Infected rainbow trout treated with two doses of isometamidium chloride}

At $3 \mathrm{wk}$ postinfection significant differences were not detected in mean parasitaemias between infected fish (Groups A, B and C). Groups B and C were both treated at 3 and $5 \mathrm{wk}$ after infection. Significant differences were detected between Group A (not treated) and Group C (0.1 mg kg-1 of drug) at 1 and 2 wk after treatment, and between Group $\mathrm{A}$ and Group B (0.01 $\mathrm{mg} \mathrm{kg}^{-1}$ of drug) at $2 \mathrm{wk}$ after treatment (Fig. 1). Parasitaemias declined in all groups at $6 \mathrm{wk}$ after infection, but the treated groups (B and C) were always lower than the infected controls. However, at this time the parasitaemias were not significantly different (Fig. 1).

Significant differences were not detected in PCV between infected controls (Group A) and Groups B and $C$ at 2,3 , and 4 wk postinfection. A significant difference was detected between infected controls (Group A) and fish treated with $0.01 \mathrm{mg} \mathrm{kg}^{-1}$ (Group B) of isometamidium at 2 and $3 \mathrm{wk}$ after treatment. The PCV in Groups B (treated with $0.01 \mathrm{mg} \mathrm{kg}^{-1}$ ) and C (treated with $0.1 \mathrm{mg} \mathrm{kg}^{-1}$ ) were lower than that in infected controls at 1 wk post-treatment; however this was not sig- 


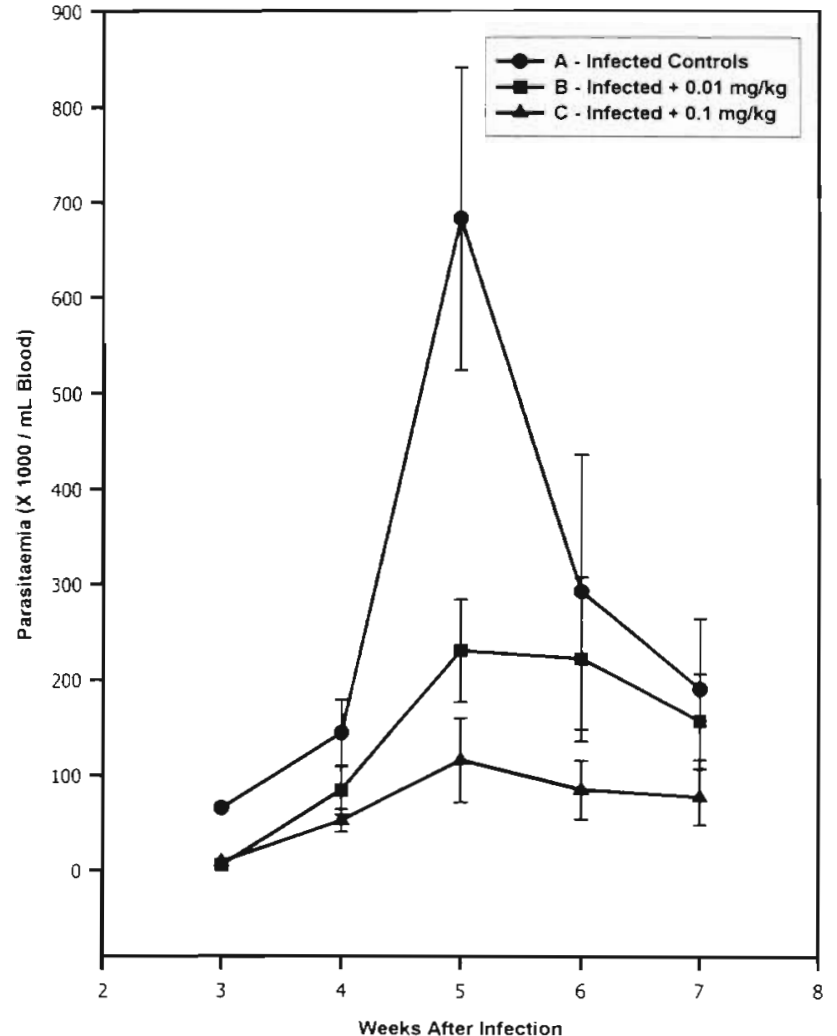

Fig. 1. Parasitaemias in rainbow trout Oncorhynchus mykiss infected with Cryptobia salmositica and treated with 2 doses of isometamidium chloride at 3 and 5 wk postinfection

nificant. The PCV in Group B and C increased after treatment and were higher than in infected controls until the end of the study (Fig. 2).

Isometamidium was not detected in infected controls; it was detectable in Groups B and $C$ at 1 wk after treatment and was highest at 2 wk after treatment. The concentration of isometamidium declined $2 \mathrm{wk}$ posttreatment and it was always higher in Group C (dose of $0.1 \mathrm{mg} \mathrm{kg}{ }^{-1}$ ) than in Group B (dose of $0.01 \mathrm{mg} \mathrm{kg}^{-1}$ ) (Fig. 3).

\section{Infected trout treated with isometamidium at preclinical and chronic cryptobiosis}

Groups $\mathrm{G}$ and $\mathrm{H}$ were treated at 2 and 3 wk after infection. Significant differences in parasitaemias were detected between infected controls (Group D) and fish treated with $1.0 \mathrm{mg} \mathrm{kg}^{-1}$ of isometamidium (Sub-group

Fig. 3. Concentration of isometamidium chloride $\left(\mathrm{mg} \mathrm{kg}^{-1}\right)$ in plasma of rainbow trout Oncorhynchus mykiss infected with Cryptobia salmositica and treated with 2 doses of isometamidium chloride at 3 and 5 wk postinfection

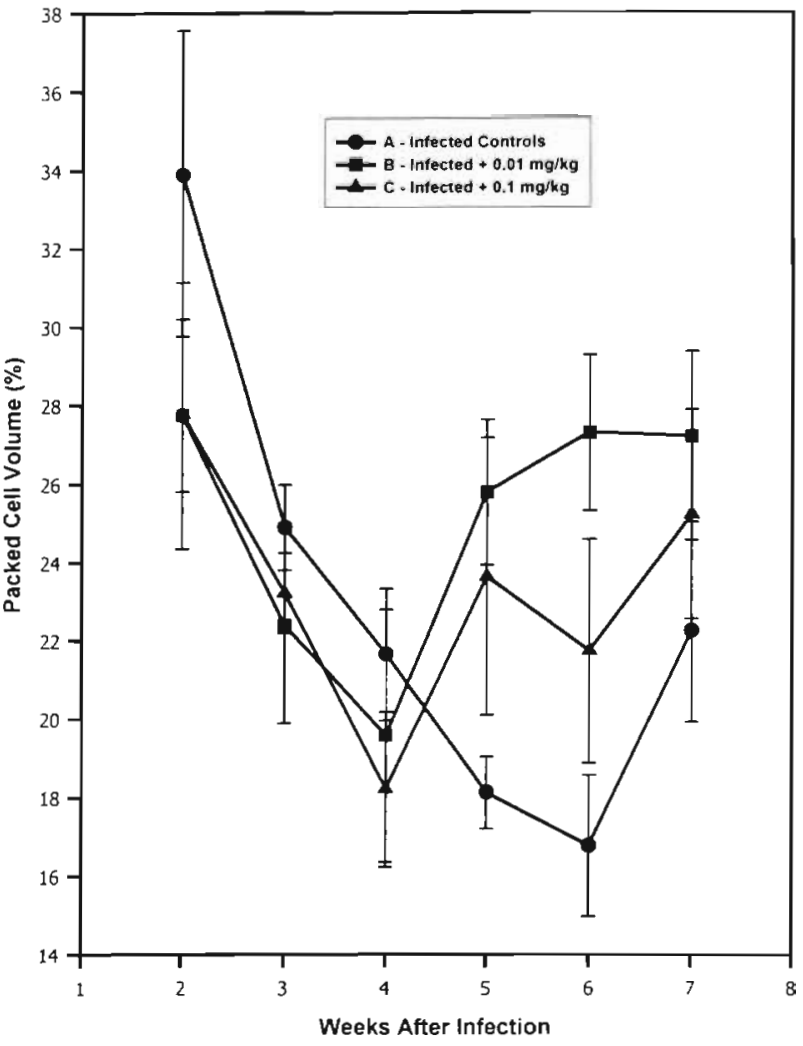

Fig. 2. Packed cell volume in rainbow trout Oncorhynchus mykiss infected with Cryptobia salmositica and treated with 2 doses of isometamidium chloride at 3 and $5 \mathrm{wk}$ postinfection

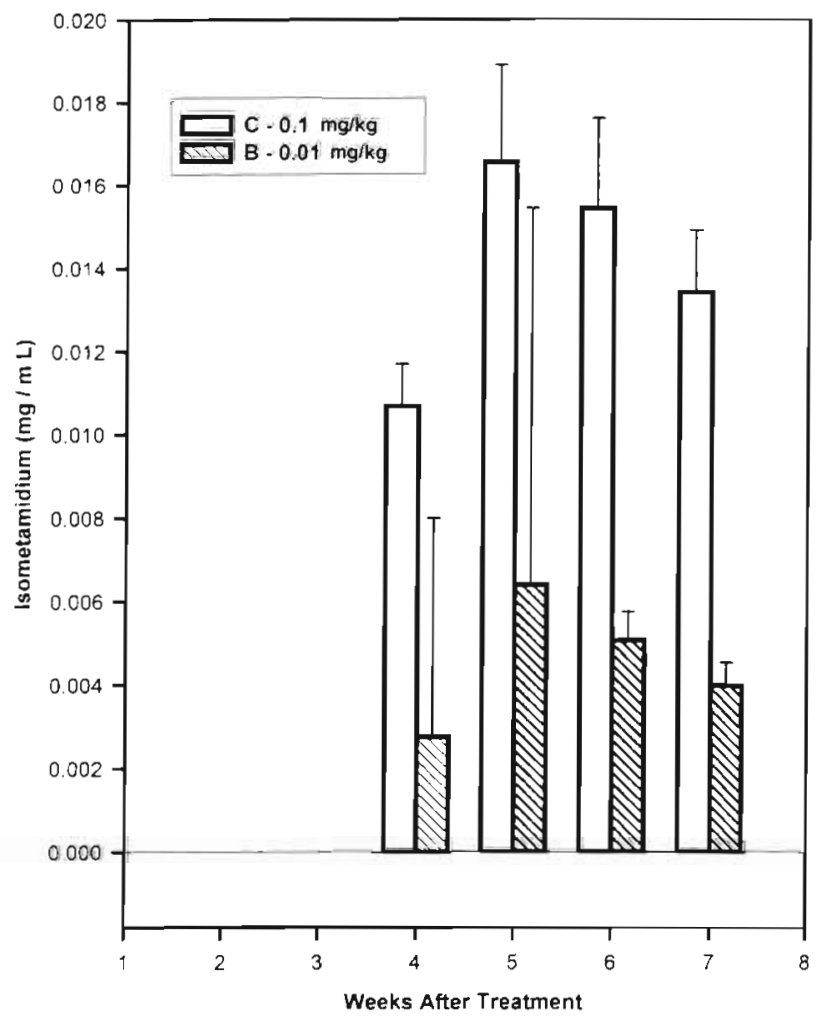




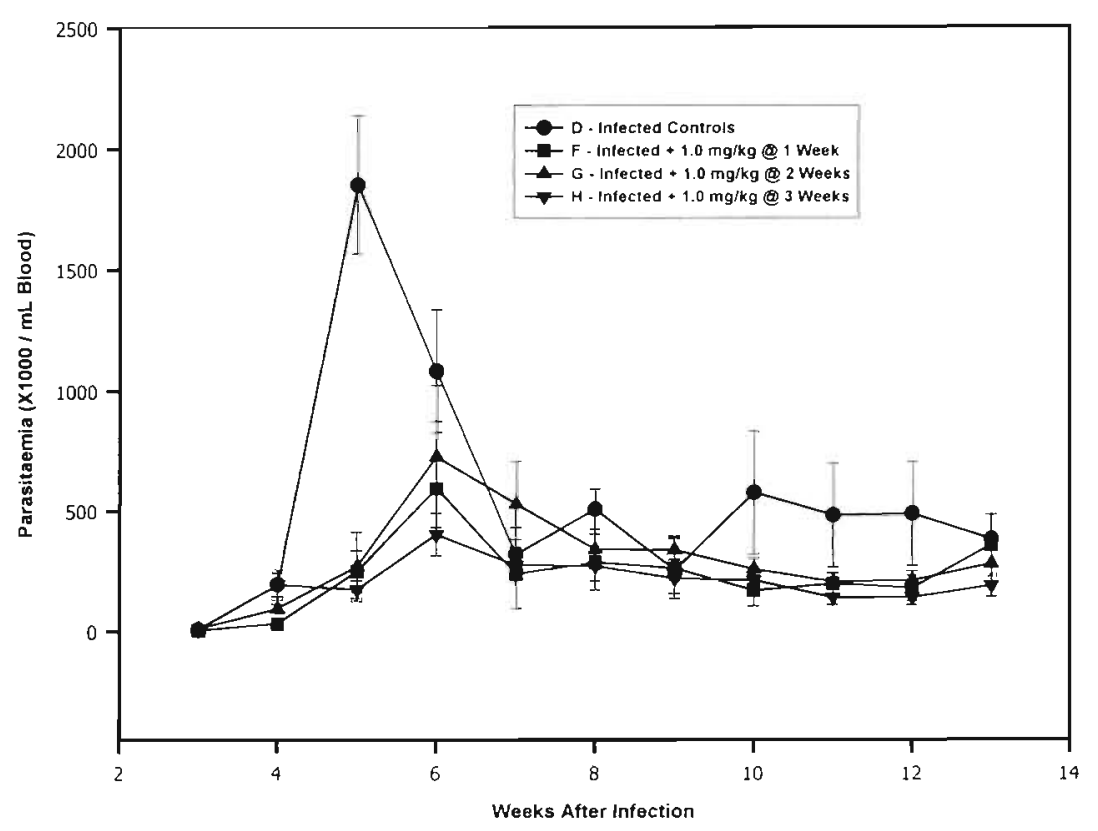

Fig. 4. Parasitaenua in rainbow trout Oncorhynchus mykiss infected with Cryptobia salmositica and treated with 2 doses of isometamidium chloride at preclinical (treated with $1.0 \mathrm{mg} \mathrm{kg}^{-1}$ at 1,2 and $3 \mathrm{wk}$ after infection) and chronic (treated with $1.0 \mathrm{mg} \mathrm{kg}^{-1}$ at $9 \mathrm{wk}$ postinfection) cryptobiosis

F1) at 4, 5, 10, 11 and $12 \mathrm{wk}$ postinfection. Significant differences were detected in parasitaemias between infected controls (Group D) and fish in Group G (treated with $1.0 \mathrm{mg} \mathrm{kg}^{-1}$ of isometamidium at $2 \mathrm{wk}$ postinfection) at $5 \mathrm{wk}$ postinfection. Significant differences in parasitaemias were detected between fish in Group D (infected controls) and between fish in Group $\mathrm{H}$ (treated with $1.0 \mathrm{mg} \mathrm{kg} \mathrm{m}^{-1}$ of isometamidium at 3 wk postinfection) at 5, 10, 11 and 12 wk after infection (Fig. 4).

At 9 wk after infection, Groups E, F, G and $H$ were treated again; their parasitaemias were significantly lower than the controls (Fig. 4).

In Sub-group F2 (treated at 1 wk) 6 of 10 fish given a single dose of $2.5 \mathrm{mg}$ $\mathrm{kg}^{-1}$ of isometamidium chloride died within several minutes of injection. Respiration seemed to cease almost immediately after fish recovered from anaesthesia; the fish had a brief convulsive episode and were dead within 5 min. The opercula and gills of treated fish were flared. The remaining 4 fish which survived the drug were not infected with Cryptobia salmositica a week after treatment while all the fish in the control group were infected and had high parasitaemias.
PCV in infected controls (Group D) were significantly lower than uninfected fish in Group $E$ (treated only with isometamidium) at $5,6,7$, $8,9,10,11,12$ and 13 wk after infection. The PCV in fish in Group $F$ (treated with $1.0 \mathrm{mg} \mathrm{kg}^{-1}$ at $1 \mathrm{wk}$ postinfection) was significantly higher than that in infected controls at $5,6,7,8$ and $9 \mathrm{wk}$ after infection. Fish treated at 2 wk postinfection (Group G) had significantly higher PCV than infected controls (Group D) at 5,6 and $7 \mathrm{wk}$ postinfection. Infected controls (Group D) had significantly lower PCV than fish in Group $\mathrm{H}$ (treated at 3 wk postinfection with $1.0 \mathrm{mg} \mathrm{kg} \mathrm{kg}^{-1}$ ) at $3,6,7,8,9$, 11, 12 and 13 wk after infection. $\mathrm{PCV}$ in infected and treated fish (Groups F1, G, and H) was significantly lower than the PCV in fish treated only with isometamidium between 3 and $13 \mathrm{wk}$ after infection (Fig. 5).

As in the previous experiment, the concentrations of isometamidium peaked at $2 \mathrm{wk}$ after each treatment (both preclinical and chronic) and then declined. The concentration of the drug was lowest in plasma of Groups E (naive + $\left.1.0 \mathrm{mg} \mathrm{kg}^{-1}\right), F\left(1.0 \mathrm{mg} \mathrm{kg}^{-1}\right.$ at $1 \mathrm{wk}$ ),

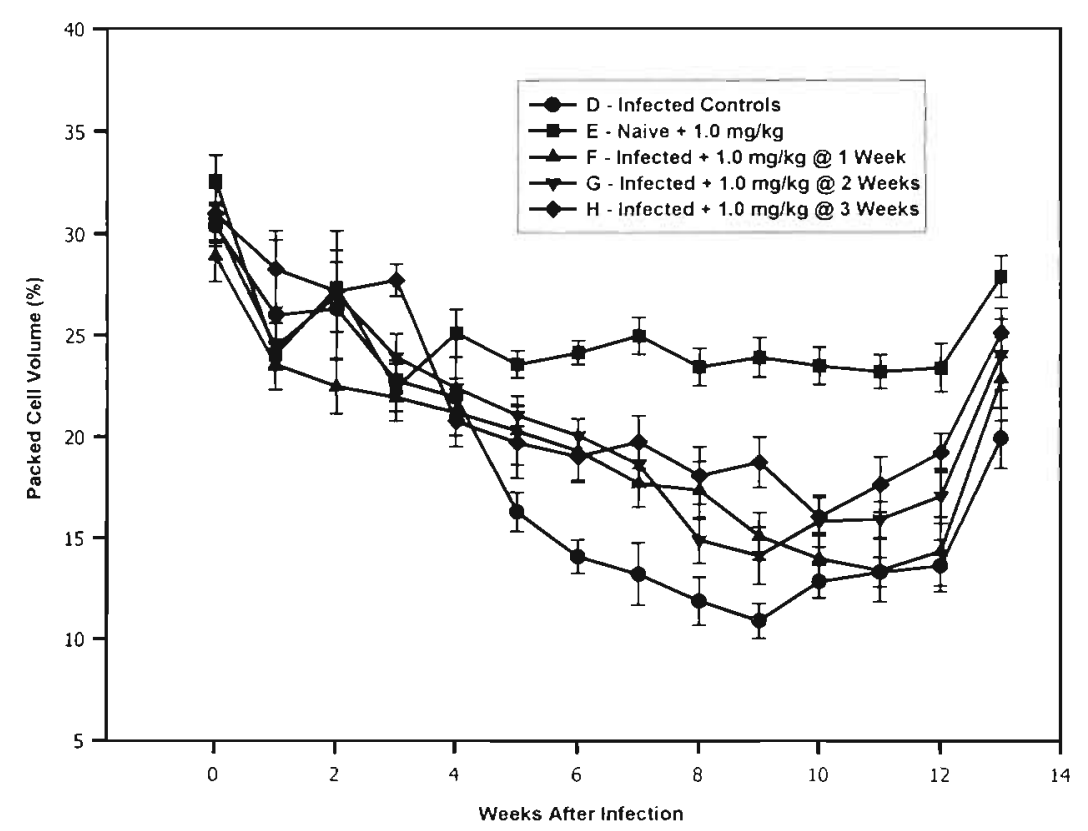

Fig. 5. Packed cell volume in rainbow trout Oncorhynchus mykiss infected with Cryptobia salmositica and treated with isometamidium chloride at preclinical (treated with $1.0 \mathrm{mg} \mathrm{kg}^{-1}$ at 1, 2 and $3 \mathrm{wk}$ after infection) and chronic (treated with $1.0 \mathrm{mg} \mathrm{kg}^{-1}$ at $9 \mathrm{wk}$ postinfection) cryptobiosis 


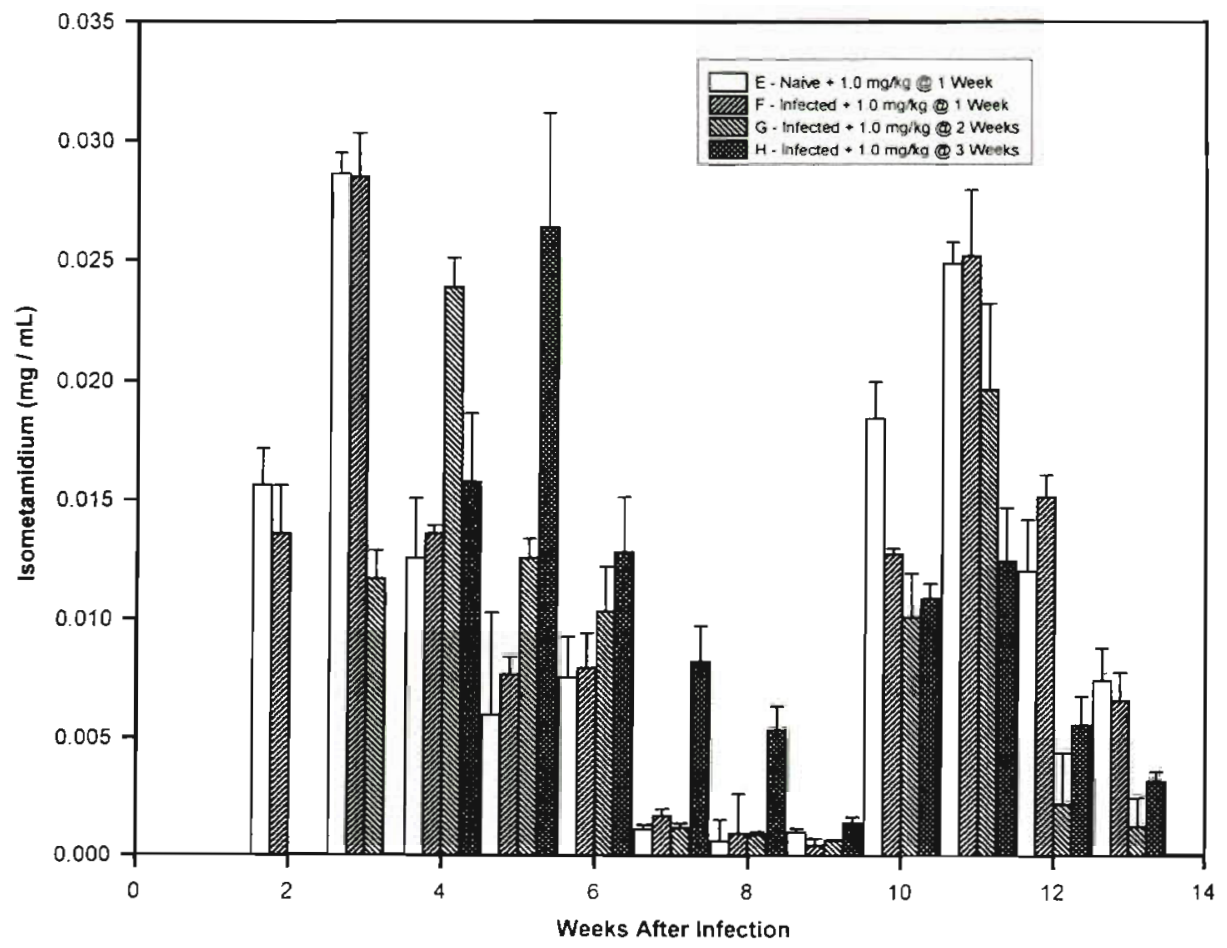

Fig. 6. Concentration of isometamidium chloride $\left(\mathrm{mg} \mathrm{ml}^{-1}\right)$ in plasma of rainbow trout Oncorhynchus mykiss infected with Cryptobia salmositica and treated at preclinical (treated with $1.0 \mathrm{mg} \mathrm{kg}^{-1}$ at 1,2 and $3 \mathrm{wk}$ after infection) and chronic (treated with $1.0 \mathrm{mg} \mathrm{kg}^{-1}$ at 9 wk postinfection) cryptobiosis

$\mathrm{G}\left(1.0 \mathrm{mg} \mathrm{kg} \mathrm{kg}^{-1}\right.$ at $\left.2 \mathrm{wk}\right)$ and $\mathrm{H}\left(1.0 \mathrm{mg} \mathrm{kg}^{-1}\right.$ at $\left.3 \mathrm{wk}\right)$ at 7 to $9 \mathrm{wk}$ after infection ( $6 \mathrm{wk}$ after treatment). The concentration of drug increased $1 \mathrm{wk}$ after the second dose of isometamidium, and declined for all groups at 3 wk after the second dose (Fig. 6).

\section{Isometamidium in Oncorhynchus mykiss during acute cryptobiosis}

Expt 1. Isometamidium did not significantly reduce the Cryptobia salmositica infection in rainbow trout during acute cryptobiosis. Parasitaemias in fish in Group $\mathrm{J}\left(1.0 \mathrm{mg} \mathrm{kg}{ }^{-1}\right.$ of isometamidium at $5 \mathrm{wk}$ ) decreased $1 \mathrm{wk}$ after treatment, and were lower than parasitaemias in infected controls; however the difference was not significant. A week later, the parasitaemia in Group $J$ increased and was higher than that in infected controls. A similar pattern was seen in Group $\mathrm{K}$ (treated at $6 \mathrm{wk}$ ); the parasitaemia decreased $1 \mathrm{wk}$ after treatment and was lower than that in infected controls, after this initial decline it increased. This pat. tern was not observed in Group L (treated at $7 \mathrm{wk}$ ) as parasitaemia did not decrease with treatment and remained higher than that in infected controls.

PCV was lower in treated fish (Groups $\mathrm{J}, \mathrm{K}$, and L) than in infected controls at $7 \mathrm{wk}$ after infection. Fish began to recover at $8 \mathrm{wk}$ postinfection, and PCV in treated fish was higher than in infected controls (Group I) at 8 and 9 wk after infection; differences were not significant.
Expt 2. This study was to confirm that isometamidium is not effective in trout against Cryptobia salmositica during acute cryptobiosis. No significant difference was

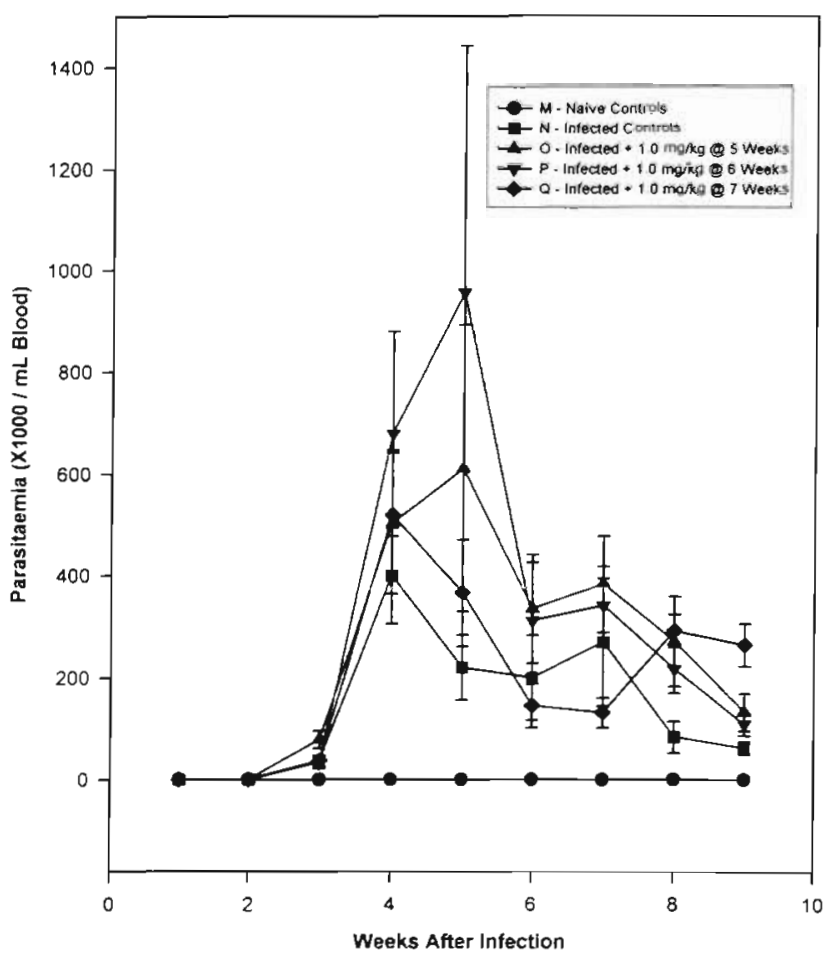

Fig. 7. Parasitaemias in rainbow trout Oncorhynchus mykiss infected with Cryptobia salmositica and treated with $1.0 \mathrm{mg}$ $\mathrm{kg}^{-1}$ of isometamidium chloride at acute cryptobiosis (treated at 5,6 and $7 \mathrm{wk}$ after infection) 


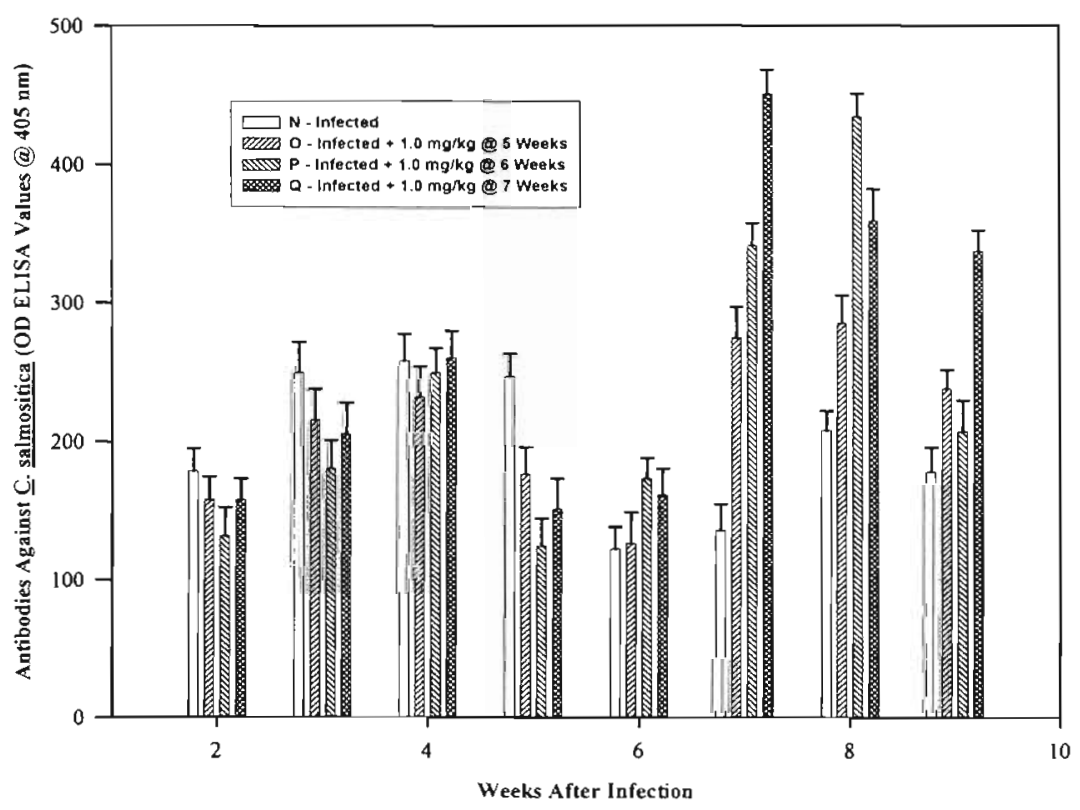

Fig. 8. Antibodies against Cryptobia salmositica in rainbow trout Oncorhynchus mykiss infected with C. salmositica and treated with $1.0 \mathrm{mg} \mathrm{kg}^{-1}$ of isometamidium chloride at acute cryptobiosis (treated at 5,6 and $7 \mathrm{wk}$ after infection). OD: optical density

detected in parasitaemias at 1 and 2 wk post-treatment between infected controls (Group N) and fish treated at 5 (Group O), 6 (Group P) and 7 wk (Group Q) after infection. Parasitaemias in fish in Group $O$ (treated at 5 wk) became significantly higher than infected controls at 8 wk after infection ( 3 wk after treatment). Parasitaemias in treated fish (Group O) fluctuated after treatment and remained higher than that in infected controls. Parasitaemias in fish treated at $6 \mathrm{wk}$ postinfection (Group P) increased at 1 wk after treatment, then declined but remained higher than parasitaemias in infected controls. Similar results were in Group Q (treated at 7 wk postinfection) as parasitaemias increased after treatment (Fig. 7).

A significant difference was not detected in PCV between infected controls and fish treated at 5 (Group O), 6 (Group P) and 7 wk (Group Q) postinfection. PCV in infected controls (Group N) and treated fish declined at $2 \mathrm{wk}$ postinfection and was lowest at $5 \mathrm{wk}$. $\mathrm{PCV}$ in infected controls and treated groups were significantly lower than naive controls between 5 and 8 wk after infection.

Using the ELISA technique antibodies against Cryptobia salmositica were not detected in naive controls (Group M). Antibodies were first detectable in all groups at 2 wk after infection. Generally, the amount of detectable antibodies (based on ELISA optical density [OD] values] increased after treatment and were higher than controls at 6 to 9 wk but the difference was not significant (Fig. 8).

A significant difference was not detected in titres of complement fixing antibody between infected controls (Group N) and treated fish between 1 and 7 wk after infection. There were significant differences between infected controls (Group N) and Group $O$, and between infected controls and Group P, and between infected controls and Group $Q$ at 9 wk postinfection. Generally, titres of complement fixing antibody increased a week after treatment in all groups and remained higher than in infected controls (Fig. 9).

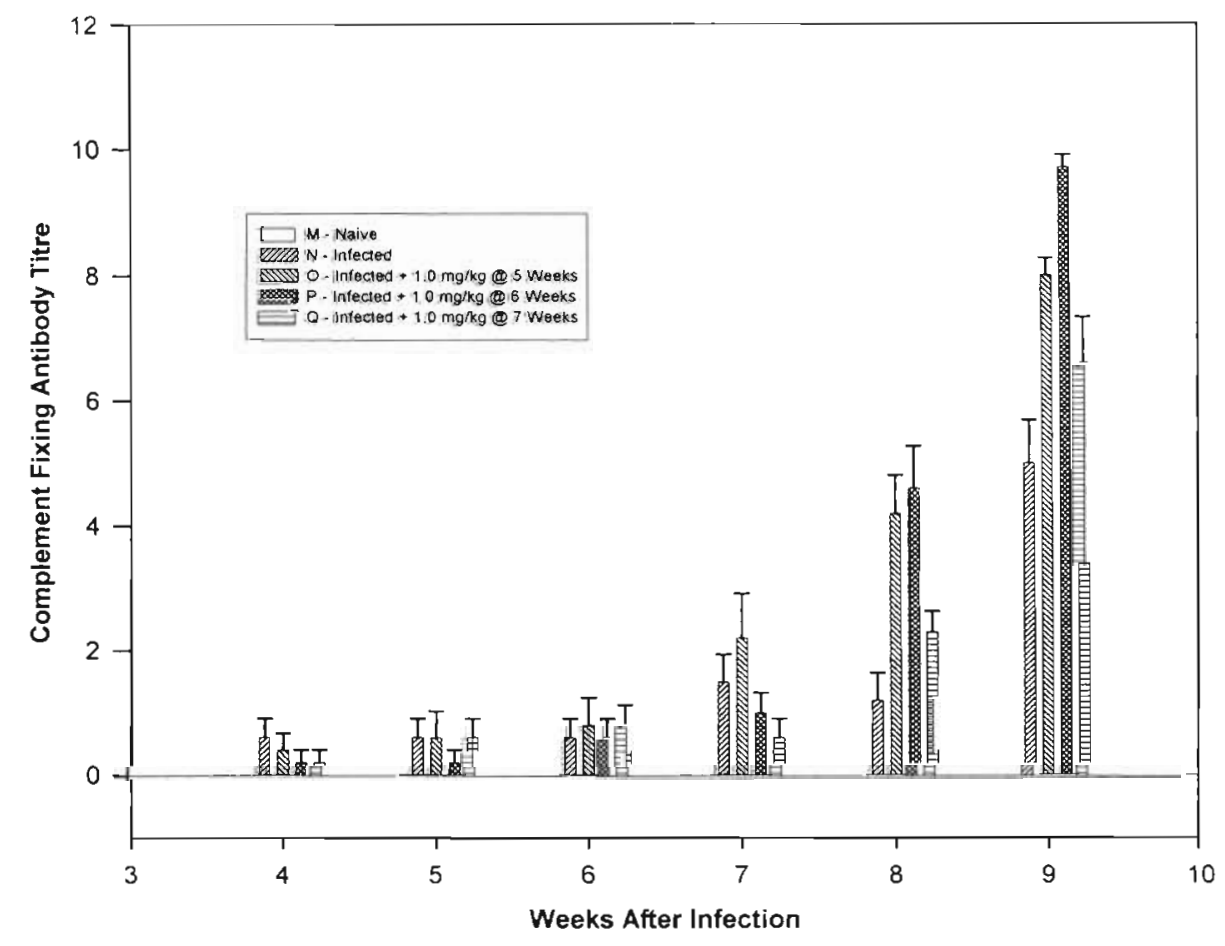

Fig. 9. Complement-fixing antibodies against Cryptobia salmositica in rainbow trout Oncorhynchus mykiss infected with C. salmositica and treated with $1.0 \mathrm{mg} \mathrm{kg} \mathrm{kg}^{-1}$ of isometamidium chloride at acute cryptobiosis (treated at 5,6 and $7 \mathrm{wk}$ after infection) 
Incubation of immune plasma with isometamidium chloride did not affect the lytic titres of 8 rainbow trout (mean titre with isometamidum $=1: 8$; mean titre without isometamidum =1:8). Similarly complement from 4 naive fish incubated with the drug did not change the immune lytic titres (mean titre without isometamidium $=1: 8$; mean titre with isometamidium $=1: 8$ ).

Concentrations of isometamidium in plasma were detectable at 1 wk post-treatment and were highest at $2 \mathrm{wk}$ post-treatment and they began to decline $3 \mathrm{wk}$ post-treatment (Fig. 6).

\section{DISCUSSION}

Isometamidium chloride is widely used to control animal trypanosomiasis in cattle, sheep, goats, buffalos, donkeys, horses, camels and dogs (Kinabo et al. 1989) and is currently the only drug available for prophylaxis in bovine trypanosomiasis (Kinabo \& Bogan 1987). Since there is no effective drug against salmonid cryptobiosis (Woo \& Poynton 1995) and there are similarities between piscine Cryptobia spp. and bovine Trypanosoma spp., we investigated the possibility that isometamidium may be effective against $C$. salmositica.

Rainbow trout injected intramuscularly at $3 \mathrm{wk}$ postinfection with $0.01 \mathrm{mg} \mathrm{kg}^{-1}$ or $0.1 \mathrm{mg} \mathrm{kg}^{-1}$ of isometamidium chloride, and given a booster at 5 wk postinfection, had significantly lower parasitaemias than infected controls. Intramuscular injection of between 0.25 and $1.0 \mathrm{mg} \mathrm{kg}^{-1}$ body weight has both therapeutic and prophylactic effects against trypanosomiasis in mammals (Sutherland et al. 1992). A dosage of $1.0 \mathrm{mg}$ $\mathrm{kg}^{-1}$ eliminated the infection in some trout; however in most cases it just lowered the parasitaemia. A higher dose (2.5 $\mathrm{mg} \mathrm{kg}^{-1}$ ) was also effective in eliminating the infection, but it also caused high mortality in fish. In rats, it was suggested the drug blocks neuromuscular transmission and stimulates cholinergic receptors with resulting paralysis. Apparently these receptor sites are occupied by isometamidium when drug concentrations are relatively high in the blood. As drug level decreases, the binding of the drug to the receptors is reversed and recovery from paralysis and other acute reactions quickly ensues (Philips et al. 1967). These may also occur in the rainbow trout which survived a high dose (2.5 $\mathrm{mg} \mathrm{kg}^{-1}$ ) of isometamidium.

In the present study it took 1 to $3 \mathrm{wk}$ after treatment before the therapeutic effects of isometamidium were observed in rainbow trout. In mammals, isometamidium declines rapidly from the plasma within the first $24 \mathrm{~h}$ after intramuscular injection (Murilla et al. 1996). The release from the site of injection was much slower in Oncorhynchus mykiss in the present study; the level peaked at $14 \mathrm{~d}$ before it declined. Temperature may affect the release of the drug from muscles and the therapeutic and prophylactic effects of the drug; cattle have a much higher body temperature than our fish, which were held at $10^{\circ} \mathrm{C}$.

Immunity is not known to increase the prophylactic effects of isometamidium in Boran cattle (Whitelaw et al. 1986). Rainbow trout that survive a Cryptobia salmositica infection are protected from subsequent challenge, and this acquired immunity is nonsterile (Jones \& Woo 1987). In rainbow trout antibodies are detectable at approximately 2 wk after infection (e.g. Woo 1990, Sitja-Bobadilla \& Woo 1994) and this was confirmed in the present study. We investigated the possibility that protective antibodies may increase the therapeutic effects of isometamidium during acute disease; however parasitaemias and lytic antibody titres were higher in treated fish compared to untreated infected controls. These observations were confirmed in our second experiment, in which fish were treated at the chronic disease phase and their parasitaemias and antibody titres were higher than those in infected controls. Generally, when the parasitaemia is high the titre of free complement fixing antibodies are expected to be low, and it increases as the parasitaemia declines (Li \& Woo 1995). This is due to C. salmositica-specific antibody being bound by antigens in the blood (Ardelli \& Woo 1997) or is used to lyse the parasite ( $\mathrm{Li} \&$ Woo 1995). In this study the amount of free specific antibody was higher in treated fish as compared to controls and this is unusual.

Humoral immunity is important in protection and complement-fixing antibody is required for fish to recover from an infection (Li \& Woo 1995). In the present study antibodies were being produced in treated fish and this suggests that isometamidium does not interfere with the secretion of immunoglobulins by plasma cells. It is possible that isometamidium decreased the effectiveness of antibodies by interfering with the complement cascade and as a result the parasitaemias were higher in treated fish. The drug may affect complement-mediated lysis by binding the important $\mathrm{Mg}^{+}$and $\mathrm{Ca}^{2+}$ ions required to activate the classical pathway. It is also likely the drug has altered the glycoprotein receptors (epitopes) for antibodies on the surface of the parasite and thus protects Cryptobia salmositica from complement fixing antibodies. These hypotheses are presently being tested. Kinabo \& Bogan (1988) have shown that isometamidium binds to tissue macromolecules and precipitates tissue proteins. We also performed 2 in vitro experiments to examine the effects of isometamidium on complement-mediated lysis. The lytic titres of immune plasma or fresh complement did not change after $3 \mathrm{~h}$ incubation with $0.02 \mathrm{mg} \mathrm{ml}^{-1}$ of isometamidium. Perhaps a longer incubation time is required. 
This study shows that isometamidium chloride is effective against Cryptobia salmositica in rainbow trout during preclinical and chronic disease phases. During acute disease the drug appears to interfere with humoral immunity in infected fish and as a result the infection in treated fish is severe. This study is part of an ongoing project on developing strategies against salmonid cryptobiosis.

Acknowledgements. This study was supported by a grant from the Natural Sciences and Engineering Research Council (NSERC) to P.T.K.W. We thank Dr Andrew Peregrine (Department of Pathobiology, Ontario Veterinary College) for the donation of the isometamidium. All experiments were conducted at the Aquatic Sciences Facility (Hagen Aqualab), University of Guelph.

\section{LITERATURE CITED}

Archer RK (1965) Haematological techniques for use on animals. Blackwell Scientific Publications, Oxford

Ardelli BF, Woo PTK (1997) Protective antibodies and anamnestic response in Salvelinus fontinalis to Cryptobia salmositica and innate resistance of Salvelinus namaycush to the haemoflagellate. J Parasitol 83:943-946

Ardelli BF, Woo PTK (1998) The in vitro effects of crystal violet on the pathogenic piscine haemoflagellate Cryptobia salmositica Katz, 1951 (Sarcomastigophora: Kinetoplastida). Parasite 5:27-36

Ardelli BF, Woo PTK (1999) An antigen-capture enzymelinked immunosorbent assay (ELISA) to detect isometamidium chloride in Oncorhynchus spp. Dis Aquat Org (in press)

Ardelli BF, Forward GM, Woo PTK (1994) Brook charr, Salvelinus fontinalis, and cryptobiosis: a potential salmonid reservoir host for Cryptobia salmositica Katz, 1951 J Fish Dis 17:567-577

Bahmanrokh M. Woo PTK (1994) The histopathology of cryptobiosis in juvenile Oncorhynchus mykiss (Walbaum). VIII Int Congr Parasitol 2:434 (abstract)

Bower SM, Margolis L (1984) Detection of infection and susceptibility of different Pacific salmon stocks (Oncorhynchus spp.) to the haemoflagellate Cryptobia salmositica. J Parasitol 70:273-278

Bradford MM (1976) A rapid and sensitive method for the quantitation of microgram quantities of protein utilizing the principle of protein-dye binding. Anal Biochem 72: $248-254$

Jones SRM, Woo PTK (1987) The immune response of rainbow trout, Salmo gairdneri Richardson, to the haemoflagellate, Cryptobia salmositica Katz, 1951. J Fish Dis 10: $395-402$

Jones SRM, Woo PTK, Stevenson RMW (1986) Immunosuppression in rainbow trout, Salmo gairdneri Richardson, caused by the haemoflagellate Cryptobia salmositica Katz, 1951. J Fish Dis 9:431-438

Kinabo LDB, Bogan JA (1987) Binding of isometamidium to calf thymus DNA and lipids: pharmacological implications. J Vet Pharmacol Ther 10:357-362

Kinabo LDB, Bogan JA (1988) The pharmacology of isometamidium. J Vet Pharmacol Ther 11:233-245

Kinabo LDB, Bogan JA, McKellar QA, Murray M (1989) Relay bioavailability and toxicity of isometamidium residues: a model for human risk assessment. Vet Hum Toxicol 31: $417-421$
Li S, Woo PTK (1991) In vitro effects of fetal bovine serum and glucose on multiplication of Cryptobia salmositica. J Parasitol 77:151-155

Li S, Woo PTK (1995) Efficacy of a live Cryptobia salmositica vaccine, and the mechanism of protection in vaccinated rainbow trout, Oncorhynchus mykiss, against cryptobiosis. Vet Immunol Immunopathol 48:343-353

Murilla GA, Mdachi RE, Karanja WM (1996) Pharmacokinetics, bioavailability and tissue residues of $(14 \mathrm{C})$ isometamidium in non-infected and Trypanosoma congolenseinfected Boran cattle. Acta Trop 61:277-293

Paterson WB, Woo PTK (1983) Electron microscopic observations of the bloodstream form of Cryptobia salmositica Katz, 1951 (Kinetoplastida: Bodonina). J Protozool 30: $431-437$

Philips FS, Sternberg SS, Cronin AP, Sodergren JE, Vidal PM (1967) Physiologic disposition and intracellular localization of isometamidium. Cancer Res 27:333-349

Sakai DK (1981) Spontaneous and antibody-dependent hemolysis activities of fish sera and inapplicability of mammalian complements to the immune hemolysis reaction of fishes. Bull Jpn Soc Sci Fish 47:979-991

Sitja-Bobadilla A, Woo PTK (1994) An enzyme-linked immunosorbent asssay (ELISA) for the detection of antibodies against the pathogenic haemoflagellate, Cryptobia salmositica Katz, and protection against cryptobiosis in juvenile rainbow trout, Oncorhynchus mykiss (Walbaum) inoculated with a live vaccine. J Fish Dis 17:399-408

Sutherland IA, Codjia V, Moloo SK, Holmes PH, Peregrine AS (1992) Therapeutic activity of isometamidium chloride in Boran cattle against a tsetse-transmitted clone of Trypanosoma congolense with a low level of drug resistance. Trop Anim Health Prod 24:157-163

Thomas PT, Woo PTK (1989) Complement activity in Salmo gairdneri Richardson infected with Cryptobia salmositica (Sarcomastigophora: Kinetoplastida) and its relationship to the anaemia in cryptobiosis. J Fish Dis 12:395-397

Wales $\mathrm{JH}$, Wolf $\mathrm{H}$ (1955) Three protozoan diseases of trout in California. Calif Fish Game 41:183-187

Whitelaw DD, Bell IR, Holmes PH, Moloo SK, Hirumi H, Urquhart GM, Murray M (1986) Isometamidium chloride prophylaxis against Trypanosoma congolense challenge and the development of immune responses in Boran cattle. Vet Rec 118:722-726

Woo PTK (1979) Trypanoplasma salmositica: experimental infections in rainbow trout, Salmo gairdneri. Exp Parasitol $47: 36-48$

Woo PTK (1990) MISET, An immunological technique for the serodiagnosis of Cryptobia salmositica (Sarcomastigophora, Kinetoplastida) infection in Oncorhynchus mykiss. J Parasitol 76:389-393

Woo PTK, Li S (1990) In vitro attenuation of Cryptobia salmositica and its use as a live vaccine against cryptobiosis in Oncorhynchus mykiss. J Parasitol 76:752-755

Woo PTK, Poynton SL (1995) Diplomonadida, Kinetoplastida and Amoebida (Phylum Sarcomastigophora). In: Woo PTK (ed) Fish diseases and disorders I. Protozoan and metazoan infections. $\mathrm{CAB}$ International, Wallingford, p $27-96$

Woo PTK, Thomas PT (1991) Polypeptide and antigen profiles of Cryptobia salmositica, $C$. bullocki and C. catostomi (Kinetoplastida: Sarcomastigophora) isolated from fishes. Dis Aquat Org 11:201-205

Woo PTK, Wehnert SD (1983) Direct transmission of a haemoflagellate, Cryptobia salmositica (Kinetoplastida: Bodonina) between rainbow trout under laboratory conditions. J Protozool 30:334-337

Submitted: May 3, 1999; Accepted: June 7, 1999

Proofs received from author(s): August 27, 1999 